\title{
MIR148A wt Allele
}

National Cancer Institute

\section{Source}

National Cancer Institute. MIR148A wt Allele. NCI Thesaurus. Code C82100.

Human MIR148A wild-type allele is located in the vicinity of 7p15.2 and is 67 bases in length. This allele, which encodes MIR148A pre-miRNA, plays a role in the regulation of gene expression. Alteration in the expression of this gene is associated with the development of asthma. 